\title{
Global crises: Is the Keynesian recipe relevant if applied under a global governance? (Some revisited issues) $^{1}$
}

\author{
TAMÁS SZENTES
}

\author{
Professor Emeritus, Member of the Hungarian Academy of Sciences, \\ Department of World Economy, Faculty of Economics, Corvinus University of Budapest \\ E-mail: tamas.szentes@uni-corvinus.hu
}

Keynesian policy was quite successful in the post-war decades in Western Europe, but by the late 1960s lost its efficiency due to changes in conditions rather than its mistaken logic. The lesson from the first global crisis erupting in early 1970s and also from the subsequent several crises since then is that the increasing crisis propensity of the world economy is rooted in its inherent disequilibria stemming from deep inequalities, asymmetrical interdependencies and disintegrated socio-economic structures. In view of the failure of the prevailing methods of crisis management, particularly those undifferentiated, antisocial austerity measures corresponding to a neo-liberal monetarist concept which neglects this lesson, many economists prefer the Keynesian recipe. However, since global crises need global solution, and the spread of conspicuous consumption modify the demand constraint, its application must be adjusted to reality, and requires some global governance which may pave the way for a global oeco-social market economy.

Keywords: globalisation, asymmetrical interdependencies, conspicuous consumerism, austerity measures, welfare state, oeco-social market economy, global governance, countervailing power

JEL-codes: ???

\footnotetext{
${ }^{1}$ This paper is mostly based on some earlier writings of the author, but brings the conclusions further and reflects his rethinking of the revisited topics in the light of new phenomena, and under the spiritual influence of the excellent booklet of Richard Jolly et al. (2012.)
} 


\section{Preface}

When, in 1974 thanks to the invitation and organisation of the Max Planck Institute we, a few scholars from different parts of the world, had an intensive one-week seminar to discuss the causes and effects of the crisis of the early 1970s, I shared the conclusion with Samir Amin, Gunder Frank, Giovanni Arrighi and Immanuel Wallerstein, that the nature of the crisis was global, and it was rooted in the anomalies, marked inequalities and disequilibria of the prevailing system of the world economy. While my above-mentioned colleagues produced a common book to summarise their views on the crisis, I wrote my own paper for, and at the very request of, a leading Hungarian social science journal, namely Társadalmi Szemle. My article, however, despite the recommending peer-reviews, was not published by the latter because its chief editor rejected it for ideological reasons. That time the official stand of the political leadership in the "socialist" countries of the Soviet bloc denied the global nature of crisis in view of the myth about "two" world economic systems and the naïve belief that the "socialist world system" is saved from any crisis. Nevertheless, I managed to find other opportunities and forums to express my views which I briefly recall and complement here.

\section{Lesson from the first global, structural and institutional crisis in the early 1970s}

In the early 1970s the crisis of the world economy was marked by the collapse of the "Bretton Woods" monetary system in 1971, by the end of the "golden decades" of economic growth and stability in the developed countries, by the spreading phenomenon of "stagflation" and finally by the oil crisis, the oil embargo and oil price explosion in 1973, which all caused a general recession in world trade and large-scale instability in the international monetary and financial relations. This crisis represented a new yardstick in the history of the world economy and also in respect of the dominant economic policy in its centre.

The crisis was the first global (and not simply "internationalised") crisis of the world economy which in one way or another, sooner or later, affected all the countries of the world, and testified more than anything else that the world economy is a single organic system with extensive and intensive interdependencies between its parts, among all the countries, whether they were its integrated components or somehow (more or less) de-linked from it. Unlike the Great Crisis of 1929 which erupted in one of the countries (the USA) and spread via the monetary and financial relations of the international banking system to other countries, i.e. became "internationalised", the crisis in the early 1970s was much less related to one particular national economy (even if the abolition of convertibility of US dollar to gold in 1971 did also contribute to its eruption), but from the very outset appeared as being directly ${ }^{2}$ or indirectly ${ }^{3}$ related to the international development gap, i.e. the centre-periphery relations, the North-South conflict, and global disequilibria of the world economy as a whole.

The former, "colonial" pattern of the international division of labour between primary producing developing countries and developed industrial countries, which inherently involved the tendency of disequilibria and the uneven development of these two groups of countries, increasingly became outdated and suffered functional troubles since the Second World War and

\footnotetext{
${ }^{2}$ Such a direct relationship was clearly demonstrated by the oil embargo, which was introduced by the petroleum exporting countries of the Middle East in the very context of the conflict between the West supporting Israel and a group of developing countries.

${ }^{3}$ An indirect relationship appeared in many ways. For example, insofar as the growing need and claim of the South for international financial assistance increasingly challenged the international monetary system. Or insofar as the efforts of the US government to prevent the extension of Soviet influence in the South led to excessive spending on military and financial aid, thereby worsening the US balance-of-payments and the position of the US dollar, on which the Bretton Woods system had been built.
} 
particularly since the mid-1950s. This followed as a consequence from changes in technologies, industrial structures, and consumption patterns in the developed countries, decolonisation itself and the investment policies of TNCs. The decreasing world market prices of primary products in the second half of the 1950s, the general deterioration of the terms of trade for the developing countries from then right through to the early 1970s and the increasingly cumulative process of indebtedness of the latter were already warning signs that this unequal division of labour with its lopsided specialisation of the developing countries could not be maintained for ever.

In the eruption of the world economic crisis in the early 1970s, a certain role was played apart from some extraordinary events like the temporary oil embargo imposed by the petroleum exporting countries or the decline in world food production caused by extremely unfavourable weather conditions in 1972 - by the coinciding of certain cyclical changes ${ }^{4}$ in the developed market economies, too. But beyond these factors there were also more fundamental factors causing, apparently the first time, a structural and institutional crisis of the world economy as an organic whole. Namely, the decline and transformation of the former ("colonial") pattern of international division of labour with built-in structural disequilibria, and the failure of the prevailing institutional system both of the world community and the nation-states to regulate efficiently the economic processes which increasingly cross the state borders.

As a consequence of the outflow or transfer of several outdated manufacturing industries from the developed to less developed countries, and/or of an ever sharper competition, caused by cheaper products exported by low-wage countries (which those old industries still remaining in the developed economies had to face), the earlier, almost "perfect" equilibrium with full employment which was achieved by post-war (Keynesian) anti-cyclical policy, necessarily broke down in the absence of co-ordinated structural and social adjustment policies. In some cases this has also undermined the position of certain strata of the working and middle classes. Thus, the basis of the welfare state was already affected not only economically but also socially by the changes preparing or following the crisis.

In view of the above, it was obvious enough that as long as deep structural inequalities maintaining and increasing the development gap characterise the prevailing system of the world economy, which are manifested in non-symmetrical interdependencies among its parts, and necessarily result various disequilibria in it, the propensity to and very background of crisis survive even if its management temporarily and partially succeeds in overcoming its most acute effects. It became also obvious that as long as crisis management remains in national framework it cannot be successful but partially and temporarily only, because a crisis of global nature necessarily requires global or at least internationally organised and coordinated management.

Thus the structural and institutional aspects of the crisis as well as its management appeared quite clearly. The above conclusions were empirically proved by a series of crises since the early 1970s, which despite the differences in their concrete form and geographical location manifested a global or globalized nature as well as structural and institutional features. It is also a fact that even the relatively most successful policy was able to overcome recession within a national economy only at the expense of unemployment remaining on high level and/or to the detriment of other countries. No doubt, the forging ahead of the neo-liberal monetarist wave of economic policies did also play a significant role in the failure of preventing new crises, moreover in generating the tendencies towards them.

\footnotetext{
${ }^{4}$ After the Second World War, for a relatively long period the business cycles of the developed market economies had not only been mitigated (by successful anti-cyclical policies) but also desynchronised (by such waves of investment as resulting from post-war reconstruction, decolonisation, arms race and technological revolution etc., which affected quite unevenly the individual countries). By the early 1970s, however, the business cycles of the USA, Western Europe and Japan became again more or less synchronised and turned into a recession.
} 
Before discussing the reasons of the change-over in paradigms and both the failure of the Keynesian and the subsequent neo-liberal monetarist ones, it is worth paying some attention to those non-symmetrical interdependencies manifesting the structural aspects of global inequalities, and to their relationship, moreover interaction with the socio-economic structures within countries, i.e. intra-society inequalities.

The asymmetrical pattern of interdependencies implies interdependencies between unequal partners. Unlike the concept of "dependence" which refers to only one side and creates the naïve assumption about the possibility of real independence in an increasingly globalized world economy, non-symmetrical interdependence is not only a more realistic concept but also points to the dependence even of the dominant part. The distinction between various forms of non-symmetrical interdependencies provides a broader perspective both for analysis and action, and reveals also some manoeuvring facilities for the weaker part, too.

Without going into details which can be read elsewhere (Szentes 2003: Ch. III/3), it seems enough to note that asymmetries may appear in the pattern of the following variants of economic interdependence:

(a) International trade relations and structural positions in the world division of labour (as manifested in the disproportionate export and import structures, i.e. in the geographical and commodity patterns of trade, which make some countries more intensively dependent, more vulnerable vis-à-vis foreign markets, and in the unequal pattern of specialisation, i.e. in the disequalising distribution of the various roles in production and service activities of the world division of labour)

(b) International ownership relations (not only because of differences in natural endowments or a given condition of factor endowments in general, but also and mainly because of the non-symmetrical flows of foreign direct investment capital and the resulting inequality in the stock of foreign capital assets)

(c) International financial relations, namely between creditors and debtors as well as those providing and those receiving international financial assistance (which are manifested in the growing, cumulative indebtedness of a number of countries and their heavy reliance on external financial resources, making them subject to the control or influence of the creditors and donors)

(d) International monetary relations, i.e. in respect of the international role, relative position, value, reserve base, and stability of national currencies, as well as their supply and demand conditions, and their relationship, exchange rate changes, etc. (which all show not only a large-scale inequality in the monetary position of countries but also a hierarchic order, a pyramidal structure of the monetary system with a few leading and also reserve currencies on the top, many convertible but weaker currencies in the middle and numerous "soft", non-convertible or not fully convertible currencies on the bottom)

(e) International technology transfer and technological relations, namely between those developing, producing, selling or transferring modern technologies, and those receiving or buying and adopting only the technologies developed by others (which results from and also tends to reproduce the very unequal distribution of research and development capacities and technology production among countries, even if no country can do without imported technologies today)

(f) International labour migration (however limited, administratively restricted it is), which besides a less significant two-ways flow is characterised by the regular outflow of unskilled or semi-skilled cheap labour from the less developed regions, seeking for employment in more developed countries, and by the immigration of the most qualified, highly educated manpower, particularly scholars, scientists and artists into the most developed countries (i.e. brain drain)

(g) International flows of information, namely in the relations between those producing, providing, selling, disseminating, spreading information and those receiving or buying them, which cause great many disadvantages for the latter not only in cost and time but also in reliability and cultural effects.

(h) International relations between those initiating new rules, international regulations or changes in the pattern of production and consumption, and those compelled to adjust to them.

While the conventional explanations on "underdevelopment" emphasised and blamed the internal factors, conditions and policies of the countries concerned, and the opposite explanations, criticising them, stressed and accused the external forces, imperialist actions and adverse trade conditions, reality does not verify any of such biased, one-sided explanations. 
The major determinants of economic development of nations (more precisely: societies within state frontiers) have been changing in the history of the world economy and have also varied from regions to regions, from country to country.

Whatever internal factors are blamed for "underdevelopment", each of them may result from the unequal international conditions, from non-symmetrical interdependencies, while whatever external, international forces, factors or effects are taken as its cause, they may follow from the given internal conditions, too. Such a note does not mean a tautology, a circular reasoning, because the cause-effect relationship can always be determined but only in terms of specific places and time. This is what I call "dialectical cause-effect relationship".

The structural distortions (disintegration) of the economy and society, manifested in the rise of enclave sectors of economy and in the alienation of a narrow elite from the masses of society, clearly wear the marks of external effects, unequal international relations. However, an economy and society with such structural distortions (disintegration and lack of cohesion), once coming into existence, necessarily create a basis for asymmetrical interdependencies, i.e. unequal international relations. All these point to the interactions of external and internal conditions.

While the existence and survival of a disintegrated, dualistic structure of the economy and society in the developing countries refer to historical causes and roots of "underdevelopment", the mechanism of such an economy and the behaviour of such a society, as well as the complexity of the resulting effects and tendencies already show the relative autonomy and self-reproducing spontaneity of underdevelopment as a historical product. This sheds light on the historically and logically determining relationship between external and internal aspects of underdevelopment, the interactions of the "internal" and "external" causes of it.

Although great many changes have taken place in the world economy and its various parts since the 1970s, both the asymmetrical pattern of global interdependencies and the problem of socio-economic disintegration have remained. Moreover, the former has extended and deepened further, the latter (while dwindling in a few countries) became manifest even in several developed countries, too - as consequences of the changes in the world economy.

The lack of integration in the economy and of cohesion in society, i.e. a disintegrated socio-economic structure provides a basis for unequal international relations, i.e. nonsymmetrical interdependencies. Due to its various effects on human resources, accumulation and use of capital, domestic market, social behaviour, culture, etc., it also hinders the development of the countries concerned (Szentes 1971:166-282 or 2003:101-171). It creates or increases disequilibria within their own economy which affect others' as well.

Consequently, an appropriate national development strategy requires efforts both to improve the position in the global patterns of interdependencies and to promote or maintain integration in the national economy as well as cohesion in the society. Disequilibria within national economies tend to lead to crisis, and hardly remain isolated in a globalised world economy.

The lesson from the first global, structural and institutional crisis of the world economy is quite simple and easily understandable. Like a human body which cannot remain healthy and operate normally if its parts are supplied and develop very unevenly, and the resulting disequilibria, unless treated, cause (as a crisis) danger for life, the world economy which has become also an organic system cannot avoid crises unless its deep inequalities and structural disequilibria are overcome. Thus, instead of palliatives, real therapy is needed.

Since the crisis of the early 1970s, however, quite many changes have taken place in the world economy.

\section{Major changes since the global crisis of early 1970s}


Without going into details, some of the most important changes can be summarised as follows:

(a) Unfolding of new waves of technological revolution, mainly in the spheres of communication and information

- reinforcing the primary role of human (particularly intellectual) capital in development,

- opening new fields for dynamic sectors and activities in the economy,

- providing better opportunities, accordingly, for some less-developed countries with appropriate type of (educated, trained or easily trainable, and disciplined) labour and R\&D capacities, to catch up with more developed ones.

(b) Rise of new generations of NICs in South-East Asia and a kind of rejuvenation of the economy, under a reoriented policy, in some Latin American countries (such as Brazil, Argentina, Mexico, Chile),

- leading to the appearance of new development poles in the world economy, which are complementing and also challenging TRIAD.

(c) The triumph (temporarily) of neo-liberal and monetarist paradigms based upon conventional orthodoxy of economics,

- resulting in the "Washington consensus" and

- promoting further progress in liberalisation of international trade and capital flows as well as

- world-wide spread of an economic policy shaped by liberalisation, deregulation, privatisation,

- enforcing "structural adjustment" (practically reduced to balance-of-payment adjustment and fiscal austerity measures) on the indebted less-developed countries.

(d) Aggravation, due to the inevitable penetration of external effects of global crisis, of all the inherent anomalies in the centrally planned economy of the so-called "socialist" countries (such as shortage of demanded consumer goods, overproduction of poor quality industrial goods, obsolete structure of manufacturing industry, overburdened and underdeveloped agriculture, artificial prices, irrational allocation of resources by central authorities, monopoly over foreign trade, centralised decision making, restrictions on citizen rights, etc.) corresponding to a war economy (Szentes 2003: Ch. IV.),

- leading to increasing social and political unrest, "illegal" strikes, demonstrations, moreover revolts or exodus of people, and to a final collapse of the soviet type system in Eastern Europe as well as the Soviet Union and its military bloc,

- thereby resolving the East-West confrontation, ending the arms race and ideological struggle, but also

- weakening, on the other hand, the international position and bargaining power of the South vis-à-vis the North, and its manoeuvring opportunities (Szentes 1990).

(e) An intensive acceleration of the globalisation process which has made the world economy extended "horizontally" to all the countries and deepened its "vertical" interdependencies among them, as being fuelled by

- the progressive reintegration of the former "socialist" countries in the world economy,

- the technological revolutions in communication and information,

- the global networking and worldwide activities of transnational companies,

- progress in trade and "capital account" liberalisation and spread of neo-liberalmonetarist government policies,

- the increasing interconnection among international money markets, stock exchanges (giving birth to "contagion" phenomenon). 
Globalisation has got a double-face. It causes both favourable and unfavourable effects and consequences. It tends to bring the peoples of the world, all nations and ethnic groups closer to each other, promoting mutual understanding, solidarity and a kind of planetary consciousness, but, on the other hand, it reinforces the existing inequalities and sharpens competition ${ }^{5}$ for global resources and power between states. Like regionalisation, it may help and may also hinder national development.

Under the present conditions shaped by the changes outlined above, and in the light of the increasingly obvious failure of the neo-liberal-monetarist policies to overcome or prevent crises, numerous scholars, including some of those formerly outstanding representatives of the neo-liberal mainstream of economics (see e.g. Krugman 2009) point to the very crisis of the latter and reject the applicability of the conventional paradigms of neo-liberal orthodoxy.

The concept of J. M. Keynes (or even K. Marx) is becoming fashionable again, and an increasing number of economists suggest a growth promoting Keynesian economic policy instead of austerity measures for equilibrium.

\section{The relevance (if any) of the Keynesian conception}

Large-scale unemployment is a very undesired phenomenon not only economically, as reducing the aggregate performance of the economy and its growth rate, but also socially, as depriving many people of their means of existence, and politically, as causing social unrest and working for extreme radical political forces. In view of this, Keynes' conclusion was that the governments must act in order to overcome it. The market economy cannot be left to operate spontaneously because its "invisible hand" can ensure, indeed, neither the maximum economic efficiency nor social justice and equity. ${ }^{6}$ Moreover, under "laissez faire" conditions a market economy necessarily suffers deep cyclical motions, including regularly returning crises with mass unemployment.

The cyclical motion of the economy implies changes in the level of (imperfect) equilibrium, i.e. fluctuations in the level of employment. ${ }^{7}$ Crisis - according to Keynes - erupts when the "marginal efficiency of capital" which reflects the expectations on future returns on investment, suddenly collapses, and liquidity-preference sharply increases. ${ }^{8}$ He adds (Keynes 1936) that unfavourable psychological factors also contribute to the worsening of business conditions. ${ }^{9}$

\footnotetext{
${ }^{5}$ The ambiguous concept of "national competitiveness" and the resulting ideology which is disseminating by the reports of the World Economic Forum creates the assumption of a "bellum omnia contra omnes", thereby hindering the badly needed cooperation. For a detailed critique see Szentes $(2011 ; 2012)$.

${ }^{6}$ Keynes stated: "The central controls necessary to ensure full employment will, of course, involve a large extension of the traditional functions of government. Furthermore, the modern classical theory has itself called attention to various conditions in which the free play of economic forces may need to be curbed or guided" (1936: 378-380).

7 "Any fluctuation in investment not offset by a corresponding change in the propensity to consume will, of course, result in a fluctuation in employment" (Keynes 1936: 314).

${ }^{8}$ Keynes noted: “[...] a more typical, and often the predominant, explanation of the crisis is, not primarily a rise in the rate of interest, but a sudden collapse in the marginal efficiency of capital. The later stages of the boom are characterized by optimistic expectations as to the future yield of capital-goods sufficiently strong to offset their growing abundance and their rising costs of production and, probably, a rise in the rate of interest also." For "[...] the marginal efficiency of capital depends, not only on the existing abundance or scarcity of capital-goods and the current cost of production of capital-goods, but also on current expectations as to the future yield of capital-goods" (1936: 315).

9 “"...] it is not so easy to revive the marginal efficiency of capital, determined, as it is, by the uncontrollable and disobedient psychology of the business world. It is the return of confidence, to speak in ordinary language,
} 
The psychological factors play an important role in the Keynesian concept of equilibrium and growth. Among the "ultimate independent variables" determining the growth in national income and employment (including "the wage-unit as determined by the bargains reached between employers and employed, and [...] the quantity of money as determined by the action of the central bank") Keynes mentioned "three fundamental psychological factors, namely, the psychological propensity to consume, the psychological attitude to liquidity and the psychological expectation of future yield from capital assets" (1936: 246-247).

A change in the expectations concerning the future profits may suddenly cause a drop in investments, first in the given sector and then, because of interlinkages among the various sectors of the economy, in all the other sectors as well. Keynes added that "a decline in investment primarily caused by a reversal of expectations about the expected rate of return over cost (i.e., the collapse of the marginal efficiency of capital)" is aggravated by "a sharp rise in liquidity preference - and hence a rise in the rate of interest", ${ }^{10}$ which "renders the slump so intractable". His conclusion was: "In conditions of laissez-faire the avoidance of wide fluctuations in employment may, therefore, prove impossible without a far-reaching change in the psychology of investment markets such as there is no reason to expect. [... Thus] the duty of ordering the current volume of investment cannot safely be left in private hands" (1936: 317, 320).

Thus, it is Keynes' conviction that the State must intervene (but, of course, not by means of commands and direct instructions as in the "socialist planned economies"), and regulate the operation of the market economy by anti-cyclical measures, by various monetary and particularly fiscal policies.

Keynes correctly noted: "The authoritarian state systems of to-day seem to solve the problem of unemployment at the expense of efficiency and of freedom. It is certain that the world will not much longer tolerate the unemployment which, apart from brief intervals of excitement, is associated - and, in my opinion, inevitably associated - with present-day capitalistic individualism. But it may be possible by a right analysis of the problem to cure the disease whilst preserving efficiency and freedom" (1936: 381).

The Keynesian recipe for indirect government interventions in the market economy was logically based upon the consideration of demand-constraints ${ }^{11}$ caused by over-saving and liquidity preference, ${ }^{12}$ i.e. the high propensity to save of the richer people and/or their refraining from spending their incomes on consumption or investments. Consequently, the government should directly or indirectly encourage investments and spending, by such measures of fiscal policy as e.g.

- financing from the central budget public works, ${ }^{13}$ welfare programs (for education, public health, social security, etc.) or other, "unproductive" expenditures (including, perhaps, military ones) and

- purchasing from or supporting (e.g. in research and training) private companies, and

which is so insusceptible to control in an economy of individualistic capitalism. This is the aspect of the slump which bankers and business men have been right in emphasising, and which the economists who have put their faith in a 'purely monetary' remedy have underestimated" (1936: 317).

10 "Thus the fact that a collapse in the marginal efficiency of capital tends to be associated with a rise in the rate of interest may seriously aggravate the decline in investment" (1936: 316).

11 "If the propensity to consume and the rate of new investment result in a deficient effective demand, the actual level of employment will fall short of the supply of labour potentially available at the existing real wage [...]" (1936: 30).

12 Keynes noted: "The destruction of the inducement to invest by an excessive liquidity-preference was the outstanding evil, the prime impediment to the growth of wealth, in the ancient and medieval worlds." In his views, "the primary evil is a propensity to save in conditions of full employment more than the equivalent of the capital which is required, thus preventing full employment except when there is a mistake of foresight" $(1936: 351,368)$.

13 “ [...] public works even of doubtful utility may pay for themselves over and over again at a time of severe unemployment” (1936: 127). 
- redistributing incomes ${ }^{14}$ via progressive taxation in favour of the poorer people with lower saving propensity, etc. which may all lead to increased effective demand in the market.

The government should also apply such measures of monetary policy as influencing the rate of interest $^{15}$ to decrease, making thereby money "cheap" $" 16$ and encouraging investors to borrow, while inducing the propensity to consume to increase.

Such a fiscal and monetary policy necessarily creates a deficit in the central budget which is financed by inflationary emission and credit creation (leading to a "deficit-financing" type of inflation). However, in case of underutilised capacities the resulting increase in national income is supposed, or at least hoped, to cause a growth also in the revenues of the central budget, thereby eliminating the former deficits. As long as this really occurs, inflation may not only support economic growth (in the demand-constrained economies) but can also remain temporary and be kept within narrow limits.

\section{Failure of the Keynesian recipe?}

The post-war period witnessed a more or less general introduction of the policy of (indirect) state intervention in the economy of the Western countries (to counteract downturns in the business cycle), and also welfare measures, i.e. a transition from the "organised capitalism of cartels and trusts" (Weiner 1985: 2) to a system of capitalism with "regulated"/"state-controlled" market economy and "welfare state" (or as often called: "state-monopoly capitalism").

The application of Keynesian recipe of state intervention (first, already before the war, in the form of the "New Deal" in the US) and the rise of the welfare state in the advanced Western countries after the war were the responses of the system in the centre to those accumulation and overproduction crises causing dangerous socio-political tensions, which followed from the spontaneous operation of the market economy with its tendency of capital concentration, centralisation, monopolisation and internationalisation. Just as the former transition, namely from "competitive" (or "classical") capitalism to "organised" (or "monopoly") capitalism had by no means eliminated competition, but had merely given the latter new, monopolistic or oligopolistic forms and methods, so this transition to a state-regulated welfare (or state-monopoly) capitalism with a "social market economy", could by no means eliminate the fragmentation of the control of capital (Amin 1973) and market spontaneity. It did not fully transform the system but substantially modified it not only by the application of indirect state intervention in the economy (the Keynesian monetary and fiscal policies) but also by a (further or re-) democratisation of the political system. All these were also connected with the aim of preventing a communist rule and

\footnotetext{
14 ، [...] measures for the redistribution of incomes in a way likely to raise the propensity to consume may prove positively favourable to the growth of capital. [...] in contemporary conditions the growth of wealth, so far from being dependent on the abstinence of the rich, as is commonly supposed, is more likely to be impeded by it" (1936: 373).

15 "Thus the remedy for the boom is not a higher rate of interest but a lower rate of interest. [...] The remedy would lie in various measures designed to increase the propensity to consume by the redistribution of incomes or otherwise; so that a given level of employment would require a smaller volume of current investment to support it. [...] Whilst aiming at a socially controlled rate of investment with a view to a progressive decline in the marginal efficiency of capital, I should support at the same time all sorts of policies for increasing the propensity to consume" (1936: 322, 324-325).

16 "The expectation of a fall in the value of money stimulates investment, and hence employment generally, because it raises the schedule of the marginal efficiency of capital, i.e. the investment demand-schedule [...]" (1936: 141142).
} 
Soviet influence, and with the efforts to demonstrate the vitality and superiority of the capitalist (market) system versus a communist, Soviet-type "socialist" (centrally planned) one.

The modification of the system of market economy and its operation within the developed countries implied a new "social contract" seemingly between the working classes and the capitalist class ${ }^{17}$ as well as between the latter and the State. It damped down "class struggle" and involved the trade union bureaucracies and/or (social democratic) labour parties in the management of business and state politics, respectively, thereby allowing such "countervailing forces" of capitalism to reform and to a certain extent correct the operation of the latter after the Second World War. Differences, of course, appeared among the concrete variants, depending on the world position of the countries concerned, such as between a welfare state with a so-called "social market economy" and a more individualistic, liberal variant coupled with the dominant role of a military and industrial complex, or a kind of corporative system. Nevertheless, what is called capitalism has become quite different in the developed Western countries from the one criticised by Marx and others in the $19^{\text {th }}$ century or even the one which was existing and burdened with enormous social conflicts and economic disequilibria there before the Second World War.

In the post-war period the governments in Western Europe, almost without exception, successfully applied the Keynesian anti-cyclical policy to treat and diminish disequilibria in the economy, to avoid or eliminate mass unemployment, great cyclical recessions and overproduction crises. Such a policy applying progressive taxation to redistribute incomes in favour of the poor, and various fiscal and monetary measures to stimulate production and investment by increasing expenditures on public health, education, social care, science and culture, proved quite efficient in the first two decades after the Second World War, and contributed to the development of the welfare state and social market economy in the Western countries.

However, the spectacular success of the Keynesian economic policy did not last long in the advanced West.

As a consequence of the outflow or transfer (by transnational corporations, TNCs) of several outdated, mainly labour-intensive manufacturing industries from the developed to less developed countries, and/or of an ever sharper competition, caused by cheaper products exported by low-wage countries (which those old industries still remaining in the developed economies had to face), the earlier, almost perfect equilibrium with full employment which was achieved in the first post-war decades, necessarily broke down in the absence of co-ordinated structural and social adjustment policies. This fact itself, together with the growing legal or illegal immigration of people from the less developed countries necessarily undermined the position of certain strata of the wage and salary earning classes of the developed countries. Thus, by the changes preparing or following the crisis, the very basis of the welfare state has been affected not only economically but also socially.

Towards the end of the 1960s, the Keynesian economic policy, which was elaborated for, and applied within, the national framework of economy, regulating the economic processes by market-conform methods within the latter, became less and less efficient, moreover, led finally to increasing inflation together with a slowing down of economic growth, i.e. to "stagflation". Its "failure" was most likely due to the fact that progress in globalisation and regional integration as well as the expansion of TNCs' activities have made the national framework of regulation of economic processes increasingly outdated and irrelevant.

The decreasing efficiency of the anti-cyclical (Keynesian) policy and the increasing difficulties in applying its methods of state intervention to regulate the operation of market economies in order to reach or keep perfect equilibrium, necessarily followed from a sharpening

\footnotetext{
${ }^{17}$ Such a rather clear-cut division line between the working and the capitalist classes as existing in the $19^{\text {th }}$ century and considered by Marx, has been increasingly blurred since then, as a consequence of differentiation within both classes and appearance of intermediate and marginalised strata.
} 
contradiction between, on the one hand, the national framework for which such a policy was elaborated and its tools were applied, and, on the other, the actual sphere, much wider by far, of those real economic activities to be regulated. Globalisation, transnationalisation and regional integration sharpened this contradiction between the framework of institutional competence and that of activities.

The expanding activities and global networks of the transnational companies have "internalised" an increasing part of international trade in the form of transfers between their own subsidiaries operating in different countries. The consequence of this is exemption of them from national control and normal market mechanisms. Since TNCs follow the strategy of a more or less "global optimisation" and "global sourcing", they may respond to government measures of regulation in a given country quite differently or even contrary to how the national firms would do. Consequently, state regulations and anti-cyclical government policies may not be as effective in their presence as without. By using their subsidiaries to shift certain activities (really or seemingly only) to another country, the TNCs could easily escape from the effects of state regulation in a single country. This fact itself points to the inadequacy of the institutional framework of competence of the "nation-states" for regulating the increasingly transnationalised economic processes and actors.

Another factor undermining also the competence and ability of the nation-state to regulate economic processes has been, of course, regional integration, particularly the one proceeding in West Europe, which resulted first in a common market (also for factors of production), and developed further to an "economic union" (namely, to the European Union).

A certain paradox appeared: the post-war period until the late 1960s saw the Keynesian policy of anti-cyclical state intervention in national economies being widely introduced and rather successfully applied in individual Western countries, while the same period also witnessed the growth of counteracting tendencies which undermined its basis and the very framework within which such a policy was and could be successful.

The world-wide activity of TNCs, regional integration, and the progress, in general, in globalisation, all resulting an expansion of world-wide interdependencies, would have already called for a machinery of regulation also on a global, world-economic level. However, the existing international institutions proved inappropriate and unable to effectively regulate the economic processes crossing state borders, ${ }^{18}$ while nation states have lost their ability to regulate their "own" national economy.

Consequently, we may conclude that it was not the very concept of Keynes which has failed, but the changes of circumstances deprived it of relevance for individual countries. ${ }^{19}$

The monetarist "counter-revolution" versus the Keynesian "revolution" missed to recognise the appropriate logic of the Keynesian recipe but if applied within a more or less closed system. (Namely the very logical assumption that a moderately expansionary fiscal policy aimed at mobilising development resources and a temporarily inflationary monetary policy encouraging investments under demand constraints and underutilised capacities, may not lead to growing budget deficit, nor to an inflationary spiral, in so far as the economic actors respond normally, i.e. by increasing demand in the market, followed by increased investment, which result in economic growth, consequently in increase of budget revenues and in demand for money.)

\footnotetext{
18 "The current governance arrangements are faulty on two basic grounds. They are ineffective: the structures do not have the coherence and the leverage required to address the complex challenges of globalisation. And they are unrepresentative and therefore deficient in terms of legitimacy: they still essentially reflect the structure of world economic power and influence as it was in the mid-twentieth century" (Jolly et al. 2012: 54).

${ }^{19}$ It is to be noted that the relevance of the Keynesian policy was already questioned, moreover denied for the case of underdeveloped economies in the mid-1960s (See e.g. Rao 1964).
} 
What seems to follow is that the same policy, if adapted to and applied within the global framework of the world economy, may be appropriate and efficient. However, the case is not so simple.

The recent crises have revealed some other aspects of their background and also considerable differences in "demand constraints". Moreover, a global application of the Keynesian policy requires specific conditions in the institutional system, including a mechanism of regulating economic processes on world level, orienting investments and consumption towards basic human needs, ${ }^{20}$ a management of global public goods and non-renewable resources, a kind of world budget and global public sector financed by international taxes, a redistribution of incomes in favour of the handicapped, a control over the worldwide activity of TNCs and big financial institutions, etc. In other words, it requires a system of "global governance" empowered with enforcing means, and sufficient support for reforming accordingly the prevailing institutions and/or creating new ones for the above task.

\section{Some neglected aspects in the prevailing crisis management}

Most of the explanations on the causes of crises fail to reveal, and all the prevailing policies of crisis management fail to treat the deeper roots and general background of global crises, particularly the increasing crisis propensity of the world economy as manifested in international and intra-society inequalities. ${ }^{21}$ Moreover, they also fail to recognise some new aspects and background factors behind the recent crises.

While the increasingly globalized economic crises of various types and with different epicentres are cyclical, there is an almost permanent crisis of the world society, which is multidimensional in nature, involving not only economic but also socio-psychological, behavioural, cultural, moral, and political aspects. It has developed because of the extension of the operation of the market, as being dominated by capital, beyond the economy and the normal frontiers of its original functions. Such fields of human life, too, have become subject to the rules of the market as politics, culture, arts, science, education, and sport, moreover environment protection and human bodies as well. Consequently, the spirit of selfish individualism, blind nationalism, market-type competition has been fuelled with an assumed hope in a zero-sum game. ${ }^{22}$

As another paradox, the very success of Keynesian economic policy in overcoming the demand constraint has generated (together with the political intention to demonstrate superiority of "capitalism" over "socialism") such a conspicuous consumerism in the developed Western countries as far surpassing and even moving away from real human needs. It has proved hardly sustainable in longer run. The spread of this consumerism in the West after the Second World War, and its demonstration effects on other parts of the world also contributed to the eruption of the recent crises which therefore can hardly be explained by demand constraints in general, or even by purely economic factors.

Conspicuous consumerism which is usually accompanied not only by deliberate quality deterioration of mass products, but also by squandering, ostentation, and artificially created

\footnotetext{
${ }^{20}$ The idea of „basic needs oriented development” was originally raised by Louis Emmerij and his associates in the International Labour Organisation (ILO), and it has been repeatedly emphasised by a few scholars (See Emmerij 1976; and Streeten et al. 1981).

21 "Inequality is economically dysfunctional. When consumption is highly concentrated in the top wealthiest groups, an economy is inefficient, increasingly unstable and, as the IMF has shown, slow to recover from crisis" (Jolly et al. 2012: 40-41).

${ }^{22}$ A longer explanation of the over-extension of market operation was presented in my Hungarian book (Szentes 2009), while a critique on the perception of "national competitiveness" as an ideology of bellum omnia contra omnes, can be read in my papers in English (Szentes 2011 and 2012).
} 
waves of fashion, has become a social scale. It was originally based on the expanded credit system of the capital-rich Western economies as well as their still cheap energy and raw material imports from developing countries. The growing demands of the so-called "consumer society" spreading conspicuous consumption worldwide have, therefore, not only exerted an increasing pressure on the world's non-renewable natural resources, but also made it vulnerable to the vagaries of traditional sources of supply as well as to domestic credit conditions.

The road and pattern of development which led to the rise of such a social behaviour as manifested in conspicuous consumerism along with growing indebtedness or even pauperisation, have thus also proved unsustainable in the light of the crises, expanding social unrest as well as ecological dangers. ${ }^{23}$

In addition, the demonstration effects of this "consumer society" and its life style have biased the consumption and import patterns of those countries (more precisely their elites) imitating the Western example, and this has also contributed to the growth of disequilibria in the world economy.

The continuous business propaganda of giant commercial companies as well as the ongoing irresponsible credit policy of commercial banks have intensively promoted the practice of squandering and conspicuous consumption since (and despite) the crisis they contributed.

While such austerity measures ${ }^{24}$ and restrictive economic policies as being, in general, applied nowadays ${ }^{25}$ have reduced the basic consumption of the poor in a drastic way, causing thereby spread of famine, malnutrition, and poverty, as well as decline in basic needs oriented production, they hardly touched upon the conspicuous consumption of the rich. The gap not only in development and income levels but also and particularly in the living standard and in general life conditions between a small group of the rich and the enormous masses of the poor both within most of the individual societies and in the world society as a whole has become more manifest than ever. It generates, besides causing disequilibria, a dangerous growth and spread of disappointment, unrest, hopelessness which provide the soil for the rise of extreme political forces and globalisation of terrorism.

In view of the multidimensional nature, deep roots and extensive effects of global crisis the prevailing methods and policies of crisis management can hardly be efficient. At best they may mitigate some components and effects of one or another concrete crisis erupting in a specific field of economy, but cannot reach the deeper roots and broader social background of the crisis propensity of the prevailing system of the world economy.

The neo-liberal monetarist approach to crisis management which focuses on monetary and fiscal disequilibria is by its very nature a purely economic one, representing short-sighted economism out of the context of social and international reality. The policy of undifferentiated, socially harmful austerity measures, which follows from it, may aggravate rather than solve the problem.

Most of the advocators of austerity measures and restrictive economic policies aimed at balance of payment adjustment, cut of budget deficit and arrest both of cumulative indebtedness and inflation, seem to neglect some important points. Such as:

\footnotetext{
23 "The extreme inequality in the distribution of the world's income should make us question the current development model (development for whom?), which has accrued mostly to the wealthiest. Social discontent is becoming more widespread in Europe and all over the world, and governments are losing legitimacy" (Jolly et al. 2012: 40).

24 "[...] austerity is bad economics, bad arithmetic, and ignores the lessons of history. [...] austerity measures have been reducing public expenditures for social goods and services in most countries, at a time they are most needed" (Jolly et al. 2012: 1 and 38-39).

${ }^{25}$ Austerity - in my opinion - is not necessarily bad, moreover it may be both necessary and socially favourable if it is applied to curb conspicuous consumption and spending on luxuries of the rich and to reduce prestige investments and bureaucracy of the State.
} 
- There is an inherent contradiction between the above-mentioned undoubtedly necessary targets of restoring monetary equilibrium and the harmful effects of austerity measures on the real economy which, as being kept thereby and sinking further in recession, nourishes disequilibria.

- The monetary equilibrium can be restored according to the modern monetarist theory not only by cutting down the excessive supply of money (mostly caused by deficit financing) but also by means of promoting economic growth which owing to increased amount of products may adjust the demand for money to money supply.

- There is also a certain contradiction between austerity and neo-liberal policy. The former represents massive state intervention, and aims at reducing deficits, indebtedness, inflation, thus disequilibria in general, while the latter promotes privatisation, liberalisation and deregulation, stimulates the extension of market mechanism to all spheres of society, and usually implements tax reduction in favour of the rich. As a consequence of their combination, restrictive measures are not properly differentiated; moreover, they mostly affect public health, education, social care and pension systems thereby worsening the life conditions and opportunities of the poor and low-income strata, while they hardly affect the position of the rich. Such a combination contributes to an increase in social gap, to a marked contrast between mass poverty and conspicuous richness, to excessive demands of the rich for luxurious items, coupled with constrained demand of the poor for basic goods, and thereby reinforces the tendencies of disequilibria and indebtedness. In so far as the restrictive fiscal and monetary measures increase social and/or international inequalities, they necessarily affect harmfully the real economy because of nourishing disequilibria.

- The original authors and famous pioneers of the idea of economic liberalism, such as Adam Smith, David Ricardo, John Stuart Mill, Alfred Marshall, and others, did by no means suggest (like contemporary neo-liberals) privatisation of, or the rule of the market over education, public health, culture, science, sport, and social care, etc., nor did they stand for an unlimited individualism driven by self-interest if it hurts community interests. They expressed a strong social sensitivity and urged the reduction of poverty. ${ }^{26}$

Despite such neglected points and other shortcomings of the neo-liberal monetarist concepts we cannot consider them completely useless or meaningless. Nor should we choose, instead of them, the Keynesian ones without critical consideration.

Contrary to the neo-liberal monetarist approach a kind of Keynesian approach seems indeed more relevant in so far as its emphasis is put on the need to promote economic growth for restoring a dynamic equilibrium and on income redistribution by progressive taxation in favour of the poor, as well as on a severe control and regulation over the financial sector. However, its application must be adjusted to the contemporary reality which is quite different from that in Keynes' time.

Most of the contemporary advocators of a Keynesian policy seem to neglect this fact and leave also other important conditions out of account. Such as

- Since crises of whatever type and erupting in whichever country necessarily tend to become globalized, while their background itself lies in the global economy, and nation states have lost their ability to regulate economic processes, the very framework of national economy is not any more appropriate for a Keynesian policy to be successfully adopted. ${ }^{27}$

\footnotetext{
${ }^{26}$ For some details see Szentes (2002).

${ }^{27}$ The case of a few Asian countries, mentioned in the booklet of Jolly et al. (2012: 14-16), as an example to be followed, where the "adoption of national Keynesian policies and controls" helped to overcome the economic
} 
- While crises and recessions in the past were linked, indeed, with a general demand constraint which the Keynesian recipe wished to overcome by appropriate fiscal and monetary measures, the contemporary ones are linked both with a demand constraint in regard to mass products for basic needs, and with an excessive demand for luxurious items, which is supported by demonstration effects, business propaganda and credit policy.

- In so far as the Keynesian policy is to be applied on global level, which is a relevant and rational suggestion, it requires not only an adequate institutional set-up but also a new, global "social contract" as well as "global governance" based upon worldwide coordination of economic policies.

What follows from all the above is that the choice is not simply between the neo-liberal monetarist approach and the Keynesian one. While both have certain, more or less relevant points, which can complement each other, their reconsideration, including the prerequisites of application, is necessary in the light of the prevailing conditions of reality.

No doubt, a certain combination of the above mentioned approaches may promise (albeit not a prevention of global crises, at least) a way out of economic crises within the countries concerned, in so far as austerity is properly differentiated and combined with progressive taxation. In other words, if restrictive measures to reduce deficits and restore equilibrium are addressed to unnecessary, luxurious spending, and if the higher rates both of income and value added taxes are applied to increase proportionally the share of the rich in burden and to discourage conspicuous consumption, respectively. It is also a precondition that the incremental budget revenue which results from progressive taxation is used to promote investments and economic growth. However, the very implementation of such a combined policy primarily (though not exclusively) depends on the political leadership in the countries concerned.

The narrow-minded, election-oriented, selfish behaviour motivated by thirst for power and wealth, which still characterise the political leadership almost all over the world, is not only an obstacle to lasting solutions but also a component of the global crisis.

Political democracy also suffers a crisis even in the most advanced countries, while it hardly exists in many countries yet. Nor is it prevailing internationally, in UN bodies either. Such fundamental principles of indirect (representative) democracy are completely neglected as prescribing for the elected delegates to represent the views, opinions, wants and interests of those who elected them, and ensuring the rights of the electing communities to withdraw those delegates who fail to do so.

As a consequence, neither the State in the individual countries, nor the international institutions (like the UN) are efficiently controlled democratically by the civil society. This very fact makes indeed difficult to treat properly the crises within countries and also to apply even a modified, adjusted Keynesian policy on world level which obviously requires global governance.

\section{The idea of global governance}

The concept of global governance has become a very fashionable term. Its definition has quite many variants, each pointing to some relevant aspects. The Commission on Global

crisis of 2007, can hardly be generalised. Under the conditions of accelerating globalisation and internationally unregulated worldwide activities of TNCs, governments in most countries, particularly in less developed ones, are too weak, or heavily influenced by the latter and international financial institutions are incapable to regulate their national economy. 
Governance defined it as follows: It is "the sum of the many ways individuals and institutions, public and private, manage their common affairs" (1995: 2.). Thakur and Weiss (2007) present a more concrete definition by pointing to collective efforts to identify, understand, or address worldwide problems that go beyond the capacity of individual states to solve. In the book of Jolly, Emmerij and Weiss global governance "refers to concrete cases of cooperative problem solving" and also "to the complex of institutions, mechanisms, relationships, and processes between and among states, markets, citizens, and organizations to articulate collective interests on the global plane, establish rights and obligations, and mediate differences". (2005: 47)

What appears from all definitions is that "global governance" is not (or not yet) a global government, a world state, but only a required method for solving our global problems by common efforts, which must be based upon worldwide cooperation.

\section{A few conclusions}

In addition to and also supporting those actions on the agenda aimed at regulating the fiscal sector, controlling the activities of banks and making them to serve instead of dominate the economy, and also curbing the speculative monetary transactions, particularly the flows of "hot money", etc., there is an urgent need for making gradual progress towards the development of an oeco-social market economy and welfare system on world level. While such a system may (or even should) be combined with the application of a modified variant of Keynesian economic policy, adjusted to contemporary conditions, it definitely requires an appropriate, democratic global governance and substantial reforms of institutions as well as changes in political and social behaviour.

In view of the complexity and obvious difficulty of even a gradual progress mentioned above, only some outlines of the required concrete steps and perspective scenarios can be presented here. Such as:

$>$ Extending and deepening of cooperation not only among the member-states of the $\mathrm{UN}$, but also among various professional NGOs both within countries and internationally, aiming at coordinated actions in the struggle against poverty, unemployment and conspicuous consumption, as well as against militarization and armament;

$>$ Reform of the representation system and voting order of UN in favour of global NGOs representing social strata or professions, and civil society organisations (e.g. by establishing the earlier suggested "second chamber" of Assembly), and introduction of (an ILO-type) tripartite system of interest reconciliation mechanism in all UN bodies;

$>$ Establishing of a kind of "global public sector" (Pronk: 1991) which besides the assets of existing institutions would involve extended UN services and specific investments to preserve and make use of "global goods" (such as under the sees and in space) and a related "world budget", both managed by a democratically elected economic governing body of the UN, which may also use such a public sector and budget as important means for a global anti-cyclical policy:

$>$ An international agreement on the adoption of progressive income taxation, and on properly differentiated, i.e. socially tolerable methods of austerity when it is needed, which should also be components of the conditionalities of the IMF and the World Bank;

> International standardisation of value added taxes in such a way as extending them to the financial sector, too, and prescribing high rates on luxurious goods, armaments and 
all those products and services that are harmful for health and environment, while exempting or applying low rates on basic goods and services;

$>$ Introduction of a progressive international income taxation crossing state borders, but making the individual states responsible for the collection of such taxes and their transfer to the "world budget";

$>$ Establishing of "cohesion funds" and "structural funds" (like those within the EU) in the UN, financed from the "world budget", serving to reduce development gaps and help structural changes in favour of less developed regions, and distributed in accordance with the real needs, on the one hand, and own efforts of the countries concerned, on the other, in developing public health, education, job creation ${ }^{28}$ and social care;

$>$ Making compulsory, i.e. binding, of all the fundamental, democratically reached $U N$ decisions and resolutions;

$>$ Empowering the UN to enforce their implementation (by applying at least such methods as used by the EU, IMF, WB, WTO);

$>$ An international agreement concerning, on the one hand, regulation, control and heavy taxing on the type of business propaganda and TV advertisements which induce conspicuous luxury consumption and irresponsible indebtedness, as well as on such TV programs disseminating the cult of violence, national demagogy, xenophobia, racism, and, on the other hand, encouragement of the media, particularly the TV stations to disseminate the spirit of humanism, solidarity, cooperation and respect of Nature;

$>$ Worldwide cooperation and common actions of those teachers, professors, journalists, TV reporters, and others engaged in education or mass media, who feel responsibility for the future of society, to promote a "New Enlightenment" (Szentes 2003; 2004; 2009) which liberates social science from ideologies, religions from political manipulations, deprives patriotism of nationalist demagogy, eliminates the myth about the rule of humankind over Nature and also about the war of different civilisations or cultures, and develops a planetary consciousness:

$>$ Introduction of an internationally common course on sustainable development in secondary schools and national universities (supported by UNU), and so on...

It would be, of course, naïve to assume that such and similar requirements could easily be realised without strong pressure on the dominant powers, on the political leaders of most of the countries, on the representatives of international institutions, and on the economic elite of the giant transnational companies. Such a pressure should come from "below" (hopefully before and not in the form of terrorism or an ecological catastrophe but instead), from internationally organised social movements (the "greens", "the "conscious consumers", the various trade unions, youth and women organisations, professional and scientific association, religious organisations, etc.) representing, if remaining independent of the states and business circles, a "countervailing power" 29 of civil society.

The membership with full rights of the representatives of the global civil society as such a "countervailing power" in the UN, their participation in interest reconciliation and decision making processes also of global enterprises, transnational companies, i.e. the appearance of

\footnotetext{
${ }^{28}$ An increase in unemployment is not only a consequence of crises but also a major obstacle to overcome it. It hinders economic growth as well as social cohesion which are badly needed for restoring equilibrium in the economy and society, respectively. Mass unemployment is an enormous waste of economic resources and a social disease humiliating great number of people.

${ }^{29}$ Emmerij, Jolly and Weiss (2001: 137) noted: "In many respects, a countervailing power is required for the planet... acting on a global scale to redefine the responsibility of states."
} 
"countervailing power" on global level can be the only guarantee against a tendency (even if the latter appears under the label of "global governance") towards further concentration of power and/or bureaucratic centralisation.

\section{References}

Amin, S. (1973): Le développement inégal. Paris: Edition de Minuit

Commission on Global Governance (1995): Our Global Neighbourhood. Oxford: Oxford University Press.

Emmerij, L. (1976): Employment, Growth and Basic Needs - A One-World Problem. Geneva: ILO.

Emmerij, L. - Jolly, R. - Weiss, T. G. (2001): Ahead of the Curve? UN Ideas and Global Challenges. Bloomington: Indiana University Press.

Jolly, R. - Emmerij, L. - Weiss, T. G. (2005): The Power of UN Ideas. Lessons from the first 60 years: a summary of the books and findings from the United Nations Intellectual History Project. New York: UNIHP.

Jolly, R. - Cornia, G. A. - Elson. D. - Fortin, C. - Griffith-Jones, S. - Helleiner, G. - van der Hoeven, R. - Kaplinsky, R. - Morgan, R. - Ortiz, I. - Pearson, R. - Stewart, F. (2012): Be Outraged. There Are Alternatives. Published by Richard Jolly.

Keynes, J. M. (1936): The General Theory of Employment, Interest and Money. London: Macmillan.

Krugman, P. R. (2009): "Making Mathematical Beauty for Economic Truth - Appeal to Students”, New York Times, September 2.

Pronk, J. (1991): Towards a System of Responsible Global Governance for Development. The Hague : Development Cooperation Information Department of the Ministry of Foreign Affairs.

Rao, V. K. R. V. (1964): Essays in Economic Development. Delhi - London: Asia Publishing House.

Streeten, P. - Burkij, S. J. - ul Haq, M. - Stewart, F. (1981): First Things First: Meeting Basic Human Needs in the Developing Countries. New York: Oxford University Press.

Szentes, T. (1971): The Political Economy of Underdevelopment. Budapest: Akadémiai Kiadó.

Szentes, T. (1990): Changes and Transformation in Eastern and Middle Europe: International Implications and Effects on the South and the East-South Relations. A Study for the South Commission. Geneva: South Commission.

Szentes, T. (2002): World Economics I. Comparative Theories and Methods of International and Development Economics. Budapest: Akadémiai Kiadó.

Szentes, T. (2003): World Economics II. The Political Economy of Development, Globalisation and System Transformation. Budapest: Akadémiai Kiadó.

Szentes, T. (2004): "Development and Transformation in the Contemporary World Economy", Paper for the international conference Development and Regionalism: Karl Polanyi's Ideas on World System Transformation, Nov. 5-6, 2004, Hungarian Academy of Sciences

Szentes, T. (2009): Ki, mi és miért van válságban (Who, what and why is in crisis?). Budapest: Napvilág Kiadó.

Szentes, T. (2011): "Concept, Measurement and Ideology of "National Competitiveness"”, KözGazdaság. Economic Theory and Policy 6(4): 9-59. Reprinted in: International Development Economics Associates, http://www.networkideas.org/featart/jun2012/National Competitiveness Szentes.pdf, 2012.

Thakur, R. - Weiss, T. G. (2007): The UN and Global Governance: An Idea and Its Prospects. Bloomington: Indiana University Press. 
Weiner, R. R., (1985): "Pluralism and neo-corporatism: the legacy of the New Deal and the 'social contract'”, XIII. World Congress of Political Science. IPSA, Paris. 